\title{
MANAJEMEN KESISWAAN.
}

\section{A. PENGERTIAN MANAJEMEN.}

Manajmenen berasal dari kata to manage yang artinya mengatur. Pengaturan di lakukan melalui proses dan diatur berdasarkan urutan dari fungsi-fungsi manajemen itu. Manajemen adalah proses bekerja sama antara individu dan kelompok serta sumber daya lainnya dalam mencapai tujuan organisasi adalah sebagai aktivitas majerial (Harsey, 1988: 4). Jadi, manajemen itu merupakan suatu peroses untuk mewujudkan tujua yang di inginkan.

Pengertian manajemen berdasarkan beberapa definisi para ahli:

\section{Drs. H. Malayu S.P. Hasibuana}

Manajemen adalah ilmu dan seni mengatur proses pemanfaatan sumber daya manusia manusia dan sumber sumber lainnya secara efektif dan efisien untuk mencapai suatu tujuan.

\section{Andrew F. Sikula}

Manajemen pada umumnya dikaitkan dengan aktivitas-aktivitas perencanaanya, pengorganisasiaan, pengendalian, penempatan, pengarahan, pemotivasian, komunikasi dan pengambilan keputusan yang di lakukan oleh setiap organisasi dengan tujuan untuk mengkoordinasikan berbagai sumber daya yang di miliki oleh oleh setiap perusahaan sehingga akan di hasilkan suatu produk atau jasa secara efisien.

\section{G.R. Terry}

Manajemne adalah suatu proses yang khas yang berdiri dari tindakan-tindakan perencanaan, pengorganisasian, pengarahan, dan pengendalian yang di lakukan untuk menentukan serta mencapai sasaran-sasaran yang telah di tentukan melalui pemanfaatan sumber daya manusia dan sumber daya lainnya. 


\section{Harold koontz dan Cyril O'Donnel}

Manajemen adalah usaha mencapai suatu tujuan tertentu melalui kegiatan orang lain. Dengan demikian manajer mengadakan koordinasi atas sejumlah aktivitas orang lain yang meliputi perencanaan, pengorganisasian, penempatan, pengarahan, dan pengendalian.

\section{B. Pengertian Manajemen Kesiswaan}

Manajemen kesiswaan (murid) adalah seluruh proses kegiatan yang direncanakan dan diusahakan secara sengaja serta pembinaan secara kontinue terhadap seluruh peserta didik (dalam lembaga pendidikan yang bersangkutan) agar dapat mengikuti proses belajar mengajar secara efektif dan efisien mulai dari penerimaan peserta didik hingga keluarnya peserta didik dari suatu sekolah. Nantinya akan di ketahui output dari lembaga tersebut sudah baik atau belum dari manajemen kesiswaan tersebut.

\section{PERENCANAAN PESERTA DIDIK BERBASIS SEKOLAH.}

A. Batasan perencanaa peserta didik.

Perencanaan peserta didik adalah, suatu aktivitas di muka tentang halhal yang harus di lakukan berkenaan dengan peserta didik di sekolah, baik sejak peserta didik akan memasuki sekolah maupun mereka akan lulus dari sekolah.

Ada beberapa langkah yang harus di tempuh dalam perencanaan peserta didik yaitu :

- Perkiraan.

Yang dimaksud perkiraan adalahmenyusun suatu perkiraan kasar dengan mengantisipasi kedepan. 
- Perumusan tujuan.

Tujuan ini dapat di rumuskan secara berbeda beda sesuai denagn sudut kepentingannya.

- Kebijakan.

Yang di maksud dengan kebijakan di sini adalah mengidentifikasi aktivitas-aktivitas yang dapat di pergunakan untuk mencapai target atau tujauan di atas.

- Pemprograman.

Menyusun program adalah suatu aktivitas yang bermaksud memiliki kegiatan-kegiatan yang sudah di identivikasi sesuai dengan langkah kebijakan.

- Langkah-langkah.

Yang di maksud dengan langkah langkah di sini adalah; merumuskan langkah langkah. Ada tiga aktivitas dalam hal ini, yakni aktivitas pembuatan skala prioritas, aktivitas pengurutan, aktivitas menyusun langkah-langkah.

- Penjadwalan.

Penjadwalan adalah; kegiatan-kegiatan yang telah di tetapkan uurutan prioritasnya.

- Pembiayaan.

Ada dua hal yang harus di lakukan dalam pembiayaan. pertama, mengalokasikan biaya, adalah perincian mengenai biaya yang di butuhkan dalam kegiatan-kegiatan yang sudah di jadwalkan.

D. PENERIMAAN PESERTA DIDIK BARU

\section{a. SISTEM PENERIMAAN PESERTA DIDIK.}

Ada dua sisitem penerimaan peserta didik, dengan promosi dan 
menggunakan system sleksi.

System promosi adalah penerimaan peserta didik, yang sebelumnya tanpa menggunakan seleksi. Dia yang mendaptar sebagai peserta didik baru di suatu sekolahan, di terima semua begitu saja. Karena itu, mereka yang mendaptar menjadi peserta didik tidak ada yang ditolak.

System seleksi system seleksi ini dapat di golongkan menjadi tiga golongan. Pertama, seleksi berdasarkan daptar nilai ebta murni(DANEM). Kedua berdasarkan penelusuran minat dan kemampuan(PMDK), yang ketiga seleksi berdasarkan tes masuk.

\section{b. PROSEDUR PENERIMAAN PESERTA DIDIK BARU.}

Penerimaan peserta didik termasuk salah satu aktivitas penting dalam manajemen peserta didik. Beberapa prosedir penerimasn peserta didik yaitu, pembentukan panitia penerimaan, rapat penentuan peserta didik, pemasangan/ pengiriman pengumuman peserta didik baru, pendaftaran peserta didik baru, seleksi peserta didik baru (opsi), rapat penentuan peserta didik baru, pengumuman peserta didik baru, pendaftaran ulang peserta didik baru.

\section{c. ORIENTASI PESERTA DIDIK}

Setelah peserta didik mendaptar ulang mereka memasuki masa orientasi peserta didik baru.

\section{Tujuan dan fungsi orierntasi peserta didik}

Tujuan orientasi peserta didik baru adalah sebagai berikut,

a) Agar peserta didik lebih mengenal dekat mengenai diri merek sendiri di tengah tengan lingkungan baru,

b) Agar peserta didik mengenal lingkungan sekolah, baik lingkungan fisiknya, maupun lingkungan sosialnya.

c) Pengenalan lingkungan sekolah.

d) Menyiapkan peserta didik secara fisik. 
Fungsi orientasi peserta didik:

a) Bagi peserta didik.

- Wahana untuk menyatakan diri dalam konteks keseluruhan lingkungan sosial.

- Wahana untuk mengenal siapa lingkungan barunya sehingga dapat di jadikan sebagai pedoman dalam menentukan sikap.

b) Bagi personalia sekolah atau ketenaga pendidikan, dengan mengetahui siapa peserta didik barunya, akan di jadikan sebagai titik-tolak dalam memberikan layanan-layanan yang mereka butuhkan.

c) Bagi para peserta didik senior, dengan adanya orientasi ini, akan mengetahui lebih dalam mengenai peserta didik penerusnya di sekolah tersebut.

\section{d. MENGATUR KEHADIRAN DAN TIDAK HADIR PESERTA DIDIK.}
A. Batasan kehadiran dan ketidakhadiran peserta didik.
B. Sebab sebab ketidak hadiran.
C. Peserta didik yang dating terlambat.
D. Pendekatan peningkatan kehadiran peserta didik.
E. Catatan kehadiran dan ketidakhadiran peserta didik.

\section{e. PENGELOMPOKAN PESERTA DIDIK.}

1) Urgensi pengelompokan.

Pengelompokan atau lazim di kenal dengan grouping di dasarkan atas pandangan bahwa di samping peserta didik itu mempunyai kesamaan, juga mempunyai perbedaan.

2) Wacana pengelompokan. 
Pengelompokan atu grouping adalah pengelompokan peserta didik berdasarkan karakteristik-karakteristiknya.

3) Jenis jenis pengelompokan.

- Pengelompokan berdasarkan minat(interest grouping)

- Pengelompokan berdasarkan kebutuhan khusus (special need grouping)

- Pengelompokan beregu (team grouping)

- Pengelompokan tutorial (tutorial grouping)

- Pengelompokan penelitian (researching grouping)

- Pengelompokan kelas utuh (full-class grouping)

- Pengelompokan kombinasi (combined class grouping)

- Sd tanpa tingkat(the non grade elementary school)

- Pengelompokan kelas rangkap multi-grade and multi-age grouping)

- Pengelompokan kemajuan rangkap (the dual progress plan grouping)

- Penempatan sekelompok sisiwa pada seorang siswa.

- Pembelajaran beregu.

- Departementalisasi.

- Pengelompokan berdasarkan kesukaan memilih teman

- Pengelompokan berdasarkan prestasi.

- Pengelompokan berdasarkan bakat 
- Pengelompokanberdasarkan minat

\section{F. EVALUSI BELAJAR.}

Tujuan dan fungsi evaluasi belajar siswa.

Tujuan evaluasi di kemukakan oleh bukhori (1980);

a) Untuk mengetahui kemajuan peserta didik.

b) Untuk mengetahui efisiensi metode pendidikan yang di pergunakan.

Fungsi evaluasi di kemukakan oleh sahertian (1979);

a) Untuk menentukan murid dalam kemajuan tertentu.

b) Untuk memperoleh data bagi pekerjaan bimbingan dan penyuluhan.

c) Untuk melengkapi impormasi kemajuan belajar, dan kemunduran murid.

d) Untuk memberikan motivasi terhadap hal bellajar mengajar.

e) Untuk memberikan informasi terhadap guru, murid dan orang tua tentang apa dan sampai dimana hasil kemajuan yang di capai murid murid sekolah. 


\section{TUGAS !!}

\section{PILIHAN GANDA.}

1. Tujuan evaluasi di kemukakan oleh?
a. Bukhori.
b. Ahmad.
c. Aguste comte.
d. Hakikal.

2. Fungsi evaluasi di kemukakan oleh?
a. Firda s
b. sahertian.
c. Shooli
d. james

2. Ada dua sisitem penerimaan peserta didik,antara lain?...
a. penjualan
b. rekrutmen
c. buangan
d. promosi dan seleksi. 
4. ruang lingkup MPDBS kecuali....

a.Perencanaa peserta didik,

b.Penerimaan peserta didik, meliputi;

c.Berdasarkan minat.

d.Orientasi peserta didik baru.

5. Dasar hukum MPDBS secara hierarki dikemukakan sebagai berikut,

a. uud tahun 1992 no 1.

b. Batang tubuh undang-undang dasar 1945 dan perubahannya pasal 31 ayat (1), (2) dan(3).

c. uud 1945 pasal 2 ayat 3 .

d. uud tahun2014 pasl 8

6. Pengertian manajemen berdasarkan beberapa definisi para ahli: kecuali....

a.hedward s,

b.Andrew F. Sikula.

c.Drs. H. Malayu S.P. Hasibuana.

d. Harold koontz dan Cyril O’Donnel

7. penerimaan peserta didik, yang sebelumnya tanpa menggunakan seleksi. Dia yang mendaptar sebagai peserta didik baru di suatu sekolahan, adalah penerimaan peserta didik melalui....

a. seleksi.

b. rekrut. 
c. promosi.

d.beasiswa.

8. tujuan khusus MPDBS sebagi berikut kecuali,

a. Meningkatkan pengetahuan, keterampilan dan psikomotorik peserta didik.

b. Menyalurkan dan mengembangkan kemampuan umum (kecerdasan), bakat minat peserta didik.

c. Menyalurkan aspirasi, harapan dan memenuhi kebutuhan peserta didik.

d. memenuhi kebutuhan hidup.

9.Manajemen adalah usaha mencapai suatu tujuan tertentu melalui kegiatan orang lain. Dengan demikian manajer mengadakan koordinasi atas sejumlah aktivitas orang lain yang meliputi perencanaan, pengorganisasian, penempatan, pengarahan, dan pengendalian. Yg dikemukakan oleh....
a. Harold koontz dan Cyril O'Donnel
b. hedward s,
c. Andrew F. Sikula.
d.Drs. H. Malayu S.P. Hasibuana

10. Meningkatkan pengetahuan, keterampilan dan psikomotorik peserta didik. Termasuk....
a. manfaat khusus MPDBS
b. fungsi khusus MPDBS. 

c. tujuan khusus MPDBS.
d. prinsip khusus MPDBS

\section{ESAI !!!}

1. sebutkan Fungsi evaluasi yang di kemukakan oleh sahertian (1979)!

2. Tuliskan Fungsi orientasi peserta didik:

3. Tuliskan Tujuan evaluasi di kemukakan oleh bukhori (1980);

4. Manajemne adalah suatu proses yang khas yang berdiri dari tindakantindakan perencanaan, pengorganisasian, pengarahan, dan pengendalian yang di lakukan untuk menentukan serta mencapai sasaran-sasaran yang telah di tentukan melalui pemanfaatan sumber daya manusia dan sumber daya lainnya.

5. Manajemen kesiswaan (murid) adalah?... 


\section{Kunci jawaban !!!}

PILIHAN GANDA.

1.a

2.b

3.d

4.c

5.b

6.a

7.c

8.d

9.a

10.c

Esaii.

1. a.Untuk menentukan murid dalam kemajuan tertentu.

b.Untuk memperoleh data bagi pekerjaan bimbingan dan penyuluhan.

c.Untuk melengkapi impormasi kemajuan belajar, dan kemunduran murid.

d.Untuk memberikan motivasi terhadap hal bellajar mengajar.

e.Untuk memberikan informasi terhadap guru, murid dan orang tua 
tentang apa dan sampai dimana hasil kemajuan yang di capai murid murid sekolah.

2. a. Bagi peserta didik.

- Wahana untuk menyatakan diri dalam konteks keseluruhan lingkungan sosial.

- Wahana untuk mengenal siapa lingkungan barunya sehingga dapat di jadikan sebagai pedoman dalam menentukan sikap.

d. Bagi personalia sekolah atau ketenaga pendidikan, dengan mengetahui siapa peserta didik barunya, akan di jadikan sebagai titik-tolak dalam memberikan layanan-layanan yang mereka butuhkan.

e. Bagi para peserta didik senior, dengan adanya orientasi ini, akan mengetahui lebih dalam mengenai peserta didik penerusnya di sekolah tersebut.

3. a.Untuk mengetahui kemajuan peserta didik.

b. Untuk mengetahui efisiensi metode pendidikan yang di pergunakan.

4.G.R. Terry

5.seluruh proses kegiatan yang direncanakan dan diusahakan secara sengaja serta pembinaan secara kontinue terhadap seluruh peserta didik (dalam lembaga pendidikan yang bersangkutan) agar dapat mengikuti proses belajar mengajar secara efektif dan efisien mulai dari penerimaan peserta didik hingga keluarnya peserta didik dari suatu sekolah 
DAFTAR PUSTAKA.

Arsyad, dan Sulfemi, Wahyu Bagja. (2014). Minat Siswa Tentang Keadministrasian dengan Hasil Belajar Administrasi Perkantoran. Edutecno. 9 (2), 40-50.

Sulfemi, Wahyu Bagja. (2016). Hubungan Persepsi Peserta Didik Tentang Kompetensi Guru Mata Pelajaran Sejarah dengan Hasil Belajar Mata Pelajaran Sejarah di Kelas X SMA Negeri 1 Pamijahan Kabupaten Bogor. Fascho, 5 (2), 52-70.

Drs. H. HASIBUANA P.S MALAYU (2011). Manajemen. Jakarta: PT Bumi aksara.

D:/smt 3/manajemen kesiswaan_silabus.mhtml.

Sulfemi, Wahyu Bagja. (2014). Pengaruh Motivasi dan Lingkungan Sekolah Terhadap Prestasi Belajar Sejarah Di SMA Negeri Leuwilang Kabupaten Bogor. 
Fascho : Kajian Pendidikan dan Sosial Kemasyarakatan 9 (2), 42-52.

Prof. Dr. imron ali, M,Pd., M,Si. (2012). Manajemen peserta didik berbasis sekolah. Jakarta:PT Bumi aksara 